\title{
More Becoming to a Man: Fathers, Sons, and the Novel of Education in Giorgio Bassani's IL GIARDINO DEI FINZI-CONTINI
}

\begin{abstract}
Andrea Malaguti
Summary: The article examines the dynamics of interaction between fathers and sons in Giorgio Bassani's The Garden of the FinziContini in a Lacanian perspective. In doing so, it discusses the often uncritically ascribed label of Bildungsroman as belonging to the novel in question only as an element of parody, which more keenly underscores the tension of the time between the approval of the racial laws (November 1938) and the eve of WWII (August 1939). It also provides the basis for further discussion on the identity of the narrating subject and his role in the Romanzo di Ferrara as a whole.
\end{abstract}

Giorgio Bassani's novel Il giardino dei Finzi-Contini is currently considered a modern classic. At the beginning of their recent Italian Literature: A Very Short Introduction, Peter Hainsworth and David Robey present it as an example of the interplay between personal life and political history that, in different degrees, pervades all the Italian canon (5-8). Such strong relationship between the individual subject (the first-person male narrator) and the times of the main narrative (from September 1938 to August 1939) have prompted the definition of this novel as a "largely autobiographical Bildungsroman," (Parks 16) or, even more radically, as a Bildungsroman by the book ("un Bildungsroman in piena regola"; Bausi 220). ${ }^{1}$

Il giardino certainly corresponds to Mikhail Bakhtin's rather broad definition of this subgenre; it is the story of a "man in the process of becoming in the novel" (19) who tries to adapt to the world and be accepted in it. However, Bassani's novel also contends with some crucial dynamics of the genre and eventually undermines it, as I mean to demonstrate by investigating a specific aspect: the relationship between the narrator and the father figures that he encounters. We all know that the main plot of Il giardino concerns a young Jewish man who

\footnotetext{
${ }^{1}$ Unless otherwise specified, all translations from Italian into English are mine.
} 
gets gradually closer to a prominent Jewish family in Ferrara at the eve of WWII and falls in love with the family's beautiful daughter Micòl, who rejects him. Nonetheless, Mario Barenghi suggests (89) that another very important point in the novel is the relationship between father and son. This relationship is crucial to the narrator's Bildung, and, I contend, it involves not only the narrator's father, but also other characters that can be easily considered father figures. In examining them, I shall amply refer to Jacques Lacan's theories about the father's role and function.

Preliminarily, the role of the first-person narrator needs to be clarified. Bassani professes to be a realist. His characters are real people, he says, who live on a certain street and belong to a specific social class. ${ }^{2}$ In his Romanzo, he certainly means to be historically accurate. However, he also affirms that the first-person anonymous narrator of Gli occhiali d'oro and Il giardino is very similar, but does not exactly correspond to the author. ${ }^{3}$ Even if Il giardino might be largely autobiographical, as Tim Parks says, a few details prevent complete identification between the narrator and Bassani. ${ }^{4}$ For this reason, as Lea Durante argues, the "I" does not resume a past identity at the level of discourse, but projects the author's present identity into the past in order to probe the times of the story. ${ }^{5}$ No "autobiographical contract" is in place to fictionalize the self (Lejeune), and therefore make the narration less credible. On the contrary, not only subjectivity does not undermine fidelity to history (Parussa 35 and 127), but the narrator's fictional status paradoxically guarantees the story's credibility and realism by presenting it as mere fiction. Bassani does not want to talk about himself, but about a time he has lived with particular intensity, when all contradictions of Italy's post-unitary

\footnotetext{
2 "I personaggi non sono pupazzi, per me, sono persone vere, che abitano una certa strada, che appartengono a una classe sociale." (Camon 85)

3 "Si tratta di un giovanotto molto simile a come ero io molti anni fa, ma non di me stesso: prova ne sia che non viene mai chiamato col suo nome, che anzi non ha nome." (Benassi 21, now in Opere 1323)

${ }^{4}$ For one thing, Ferrara's Liceo Classico has never been entitled to Giovan Battista Guarini, but, notoriously, to Ludovico Ariosto. For another, Bassani failed math not on his Licenza ginnasiale (1931), but on the year before (1930), and, anyway, not in 1929. I am grateful to Portia Prebys, Giorgio Bassani's longtime companion, for this information and the suggestion that autobiography be thwarted on purpose.
}

${ }^{5}$ 84-86; see also Neppi 385 note. 
history converge. ${ }^{6}$ Given the strong interlacement of personal involvement and historical inquiry, we can safely call the narrator "Giorgio" (with the caution that we would use calling "Marcel" the protagonist of Proust's Recherche; see Barenghi 90) and therefore distinguish him from the author "Bassani."

Il giardino depicts "the birth of the adult male, the individual capable of severing his attachment to parent figures and all they stand for and become an individual in his own right." (Kroha Drama 13) Kroha's further observations on the Finzi-Continis' upward mobility and closeness to the noble lifestyle (114) dovetail with Franco Moretti's main argument in his seminal study The Way of the World: the Bildungsroman in European Culture. According to Moretti, in the span of time between the French Revolution and the establishment of the nation-states the role of the bourgeoisie in society becomes more complex and articulated. The younger generation can no longer simply follow into their fathers' steps. A more complex world, constantly changing, requires young people to acquire more refined interpersonal skills. Identity is therefore entrusted into "forms of socialization-journeys, conversation, music, dance, humanistic culture-which had already developed within the aristocratic universe." (The Way ix; emphasis of the author). Only that time in history allowed the bourgeois male subject (and also the female one, in the cases of Jane Austen and George Eliot) a mobility that was unthinkable before, Moretti argues, and that the Bildungsroman fully represents by establishing values, tastes, and interpersonal sensibility (Moretti $248 \mathrm{n}$.). The main examples of such genre are Goethe's Wilhelm Meister (1795-96), Stendhal's Le Rouge et le Noir (1830), Balzac's Illusions Perdues (1837-1843), Dickens' David Copperfield (1849-1850), Flaubert's L'éducation sentimentale (1869), and George Eliot's Daniel Deronda (1876). Decades later, at the beginning of the twentieth century, the protagonist's social integration into adulthood turns into an

\footnotetext{
${ }^{6}$ In an interview with Ferdinando Camon in 1968, Giorgio Bassani declares that, from the point of view of history, his novel is also an essay on Italy between the nineteenth and the twentieth century: "Il giardino dei Finzi-Contini è, dal un punto di vista storicistico, un saggio (...) sull'Italia fra l'Ottocento e il Novecento: e ci son dentro tutte le pezze d'appoggio, non date per il gusto di darle, ma perché credo che la cronaca di per sé non conti niente, e perciò cerco di trasformarla in storia, da buon idealista." (Camon 60)

${ }^{7}$ I am taking a more decisive position than Francesco Bausi's, who chooses a rather abstract "G*." John Champagne's argument on the narrator being "queer" is based also on his being unnamed (152), but that does not mean that he is unnamable, no matter the articulate and complex problem of (sexual as well, but not only) identity in the novel.
} 
unresolved, internal conflict. James Joyce's Stephen Dedalus and Thomas Mann's Tonio Kröger confront a rigid apparatus (school, the church) and learn to function in it, but they resent it, and they neither share the socially diffused values nor do they really become adults. "The relevant symbolic process is no longer growth but regression" (Moretti, The Way 231) into the protagonist's own nostalgia of a pristine, putative origin. WWI, the cruelest trench conflict, would once and for all sanction the individual's irrelevance (The Way 229).

Bassani's work shows strong affinity with James Joyce's Dubliners and Portrait of the Artist as a Young Man. ${ }^{8}$ Equally important (and perhaps even more) are the similarities to the plots and characters of Thomas Mann's novels, recently investigated by Lucienne Kroha (Drama 37-39 and 75-84) and, with painstaking precision, by Francesco Bausi. ${ }^{9}$ However, precisely the presence of older mentors (the father figures hereby investigated) brings the Giardino closer to the classic Bildungsroman than to its pre-WWI version. For example, the main plot line is very similar to that of Le Rouge et le Noir: a bourgeois young man struggles to become independent through his talents, is endorsed by an older mentor from a family of higher status, and falls in love with the mentor's beautiful and unattainable daughter. ${ }^{10}$ Similarly, Giorgio is divided between his own bourgeois family and the Finzi-Continis, who live like the noble in Marquis Avogli's former castle, do not do any productive work, and spend all their time and energies in studying, conversing, and cultivating their personal interests (Moretti 40-41; Kroha, Drama 114). Even before entering their mansion, however, bourgeois Giorgio also lives like a nobleman of former times, in some sense: he studies literature (at the university), plays tennis, and socializes. In 1938-39, such lifestyle deeply underscores—if by contrast—-the tension of the times.

In order to provide a comprehensive explanation of the father figures in Il giardino, I shall recur to Jacques Lacan's tripartite frame of orders: imaginary, symbolic, and real (Seminar I 73-88), which I am about to explain briefly. ${ }^{11}$

\footnotetext{
${ }^{8}$ See Brian Moloney 231-43 and Venturi, "Prime risultanze di uno scrittore"

${ }^{9}$ Francesco Bausi, "Il giardino incantato: Giorgio Bassani lettore di Thomas Mann."

${ }^{10}$ Deeper examination of the relationship between Il giardino dei Finzi-Contini and Le Rouge et le Noir would probe the relevance of the Bildungsroman more in depth, but needs to be deferred.

${ }^{11}$ I shall define the subject with the masculine pronoun "he," since both Lacan's argument and mine are clearly gendered and focused on the male subject.
} 
According to Lacan, the imaginary is the ego's cathexis in the images he recognizes (or rather misrecognizes) externally, starting from his own reflection in the mirror as an infant and continuing on to a series of identifications throughout his life (Ecrits 75-81). These images constitute the illusory sense of unity and identity called the ego. Its very opposite is the symbolic order, which represents the order of thought collectively institutionalized, as it is defined in Lacan's own words: "It is the discourse of the circuit in which I am integrated. I am one of its links. " (Seminar II 89). The symbolic order is based on definitions and oppositions (especially between absence and presence; cf. Séminaire IV 67-68), and constitutes our shared judgment (in Kant's sense). We are all born in it, and through it we relate to reality as true subjects, no longer captive to one's own illusory ego, but fully capable of understanding the world around us. (Seminar I 220-38). Obverse to it stands the "real," as Lacan defines it, which is not at all the equivalent of reality. Reality is our understanding of what is around us. It implies cognition and belongs to the symbolic. Conversely, the real exists qua itself, ontologically, and not cognitively. The real is what the symbolic does not contain; it is not based on any system of difference or opposition and cannot be an object of knowledge. On the contrary, it needs to be suppressed for cognition to exist. (Lacan Seminar VII 19-70).

The subject's initiation to the symbolic order occurs through the father. In denying the son's access to the source of enjoyment (i.e., the mother) the father imposes the symbolic order, i.e., the accepted law of the taboo of incest. The father is therefore the figure traditionally associated with the Law imposed through prohibition (Écrits 230). This prohibition is marked by a sign, which is the father's name, as underscored in the pun that Lacan peruses: in French, non-du-père sounds exactly like nom-du-père. Through the 'no' comes the 'name' that the son shall bear, the name of the father imposing the law and determining the son's discovery and interpretation of the world. Nonetheless, even if eventually embodied in an actual person, the father is essentially a symbolic function, a non / nom that discloses the symbolic order. ${ }^{12}$ "It is in the name of the father that we must recognize the support of the symbolic function which, from the dawn of history, has identified the person with the figure of the law." (Lacan Ecrits 230)

\footnotetext{
12 “(...) il faut que le sujet, fille ou garçon, y aboutisse d'une façon telle qu'il se situe correctement par rapport à la fonction $d u$ père. Voilà le centre de toute la problématique de l'Oedipe" (Séminaire IV 201; emphasis mine).
} 
The imaginary father is the child's fantasy of the father, i.e., the object of the young boy's narcissistic identification. It could be a fantasy of either benevolent or malevolent omnipotence, featuring either the ideal father or the worst one ever possible (Séminaire IV 275-76). The imaginary father is at the origin of what Freud calls the "family romance," the fantasy of the little boy who is convinced that he is the child not of his own parents, but of nobler and more distinguished ones. ${ }^{13}$ Conversely, it can also be the punitive father constantly striking terror into the child's heart. Equally threatening is the real father, the veritable agent of castration, the subject of violence, whose only purpose is his surplus of enjoyment at the expense of the victim. The real father aims at preventing the son's enjoyment. (Seminar VII 307). This side of the father's figure is suppressed by the symbolic order: when recognizable, the real-the ever-present, non-formalized being not included in (but supportive of) the symbolic order-is indeed the form in which the repressed returns (Žižek, Sublime Object 153-99).

In Bassani's novel, the story of the Finzi-Continis starts being told by a father's voice. At the beginning, Giorgio's father summarizes the Finzi-Continis' events since the day they moved into the Barchetto del Duca and harshly reprieves them for having distanced themselves from the Jewish community in town. $\mathrm{He}$ is disappointed at Professor Ermanno, who refuses to subscribe to Fascism and whose nonchalant but substantial donation to the Fascist summer camp is clearly an act of spite. Only at the very end of this narrative does the reader become aware of who has been speaking: "So my father said." ("Così diceva mio padre" 331). ${ }^{14}$ Free indirect speech introduces the reader into the very social context against which young Giorgio will soon find reasons to rebel: the provincial bourgeoisie and its misplaced trust in Fascism. In Lacan's words: "It is the discourse of my father, for instance, in so far as my father made mistakes which I am condemned to reproduce." (Seminar II 89). The reader becomes aware both of a discourse that is not supposed to be reproduced and of how deceivingly and uncannily spontaneous that discourse once was.

Giorgio's different views on the Finzi-Continis emerge early. At the synagogue, their evident and perhaps flaunted diversity fascinates him as much as it disgusts his father. Giorgio's father is a modern Jew ("ebreo moderno" 345) and

\footnotetext{
${ }^{13}$ Usually aggrandized versions of his own; see "Family Romances" 300.

${ }^{14}$ All quotes from the text are from Giorgio Bassani, Opere (ed. Roberto Cotroneo, Milano, Mondadori, 1998) and will be marked only by the page number.
} 
a free thinker; he likes sports, knows only a few words of Hebrew, and might not even be a fervent believer. On the contrary, Professor Ermanno evidently masters Hebrew and seems almost moved to tears in repeating the liturgy by heart. He comes out as an ideal example, as compared to the many other attendants, whose minds are set more on ordinary matters than on God (345), and starts resembling the imaginary father that Giorgio probably fancies and from whom he expects validation. In the synagogue, where faith, ethnic and cultural belonging are confirmed and celebrated, a young Jewish boy is more likely to admire a devout intellectual praying passionately than a free thinker, whose thoughts might even be elsewhere. ${ }^{15}$

Social validation is a crucial common element between the Bildungsroman and the Giardino. More than in the synagogue, however, young Giorgio seeks validation at school, the specific high school for the classics that has minted the post-unitary Italian ruling class and intellectual bourgeoisie and is still nowadays a fundamental institution in every Italian city: the liceo classico. ${ }^{16}$ At school, the adult male from whom Giorgio expects validation is Mr. Meldolesi, the teacher of classics and humanities (who also tutors Alberto and Micòl Finzi-Contini at home). He impersonates the man of letters Giorgio intends to become. He even supports the adolescent's ego-ideal of the writer and literary scholar. ${ }^{17}$ However, Meldolesi's validation and recommendation cannot spare Giorgio the failure in math. ${ }^{18} \mathrm{Had}$ it not been charged with such strong expectations, Meldolesi's failed validation would have not caused Giorgio such distress as to send him off to Ferrara's ramparts on the day when he meets Micòl.

\footnotetext{
${ }^{15}$ This episode more closely confirms Freud's model of "Family Romance" that Lucienne Kroha recognizes as a matrix of both this novel ("Judaism and Manhood" 189; "The Same and the Different" 313) and the whole Romanzo di Ferrara (Drama 26-30).

${ }^{16}$ See Adolfo Scotto di Luzio, Il liceo classico, Bologna, Italy, 1999. Claudio Cazzola’s article "Korè l'oscura: (in)seguendo Micòl" constantly alludes to the many references to the school's curricular classics in the Giardino and contains an ample and relevant bibliography on Bassani as a schoolboy (Antognini-Diaconescu Blumenfeld 271-301).

${ }^{17}$ See Freud The Ego and the Id, 22-36.

${ }^{18}$ Furthermore, Meldolesi is an ex-seminarist: he willfully recanted the ministry, if not the faith, of the confession that patently repressed Judaism. On the contrary, Mrs. Fabiani, the math teacher who inflicts Giorgio the humiliation of failure, is equally intransigent both in her subject and in her daily prayers to the Virgin Mary (for his and the young Finzi-Continis' conversion, Giorgio supposes).
} 
Apart from school, literature is an important component of the lives of Bassani's characters, ${ }^{19}$ who form important bonds through their readings. As Franco Moretti contends, literature articulates and confirms the values of a social group (Signs 1-41). In this perspective, Micòl's choice of studying Emily Dickinson is a manifest declaration of personal and cultural independence both from her times (Della Coletta 146-151) and from her family, whose cult for the past is very well confined by national literature, Jewish history, and personal memory. Giorgio, more in line with the times, chooses an institutional figure, Enrico Panzacchi, as a subject of study for his school dissertation, but reads Trotsky on the side and shares it with his father, as an answer to the father's call for dialogue. ${ }^{20}$ The content of Trotsky's article — on the Jews being the victim of capitalist imperialism-finds father and son in agreement; but, while the father still holds on to the wishful thinking that town life may still be relatively safe (but it is unclear whether he fully believes what he says), for Giorgio the recently approved racial laws confirm what he painfully learned through his friendship with Doctor Fadigati in Gli occhiali d'oro: as a Jew, he shall face the very same hostility that Fadigati faced as a homosexual. ${ }^{21}$ By accepting the Finzi-Continis' invitation, Giorgio sides with them against his own father and espouses their avoidance of the town's social life and their resistance to Fascist power. Retrospectively, it is the only tenable position for a Jew in 1938. Giorgio's choice is not simply that of a man in his twenties, but also of the mature author projecting himself into the past. ${ }^{22}$ Both maturity and connection with the father, nonetheless, start from shared reading.

\footnotetext{
${ }^{19}$ Cristina Della Coletta’s article "La cultura del giardino: miti e appropriazioni letterarie ne $\mathrm{Il}$ giardino dei Finzi-Contini" (Modern Language Notes, 113.1, January 1998, pp. 138-63) is an essential contribution to the study of the importance of literary reference in Bassani's novel. More investigation is probably needed on how characters connect through shared readings, on which I am hereby about to jot some preliminary notes.

20 "So who then could he talk to? Was it possible that I did not understand it was me that he needed?" (McKendrick 57, with modifications); "Con chi doveva parlare, allora? Possibile che non capissi che era proprio di me che lui aveva bisogno?” (369)

${ }^{21}$ According to Lucienne Kroha, Giorgio, because of his sexual insecurity, neurotically keeps distance from Fadigati (Drama 105-07). It could be so, but I maintain that between the two characters there is as much proximity as the lifestyle and family obligations of provincial bourgeoisie allowed at the time.

22 "Nel romanzo, Giorgio è soltanto in apparenza un ragazzo come tutti gli altri. Il suo aspetto è di ventenne, ma il suo cervello e il suo cuore sono quelli di un adulto: il cervello e il cuore dello
} 
On a late afternoon at the Barchetto del Duca, Professor Ermanno wisely chooses to approach Giorgio by reciting Dante's famous lines: "It was the hour that turns the seafarers' longings homeward..." ("Era già l'ora che volge al disio..." Purgatorio VIII.1), the prelude to the Valley of Rulers, the protected enclosure where exiled Dante recognizes Nino Visconti and encounters other honest and liberal exiles as if they had been long-time friends. Similarly, the Finzi-Continis want their garden to be another enclosure of liberality, generosity, and protection for the Jewish exiles.

Sophie Nezri-Dufour defines this episode a veritable trial for Giorgio (35). It is certainly fraught with expectations. During the conversation Professor Ermanno, probably once fancied as the imaginary father, now comes out as the validator and mentor of Giorgio's literary and scholarly talent. Their connection through scholarship is reinforced by the mentioned project on Giosuè Carducci's letters to Josette Artom, once proposed to Meldolesi. The baton of literary scholarship — the core of Giorgio's ego-ideal—comes full circle between Giorgio and his mentors or, in Lacan's terms, imaginary fathers: Meldolesi (the man of letters), and Professor Ermanno (the Jewish intellectual). Professor Ermanno keeps courting Giorgio with references to literary studies and scholarship, and later makes him a steady guest, not only at the Barchetto, but also at the Magna Domus. This validation comes nevertheless with the implicit task of keeping the memory of the Jewish tradition alive. For this purpose, Professor Ermanno intends to give Giorgio his publications on the history of Venetian Jews, and suggests to him that he visits the old cemetery on the ghetto. ${ }^{23}$ Upon recognition of his talents, Giorgio is entrusted with the Finzi-Continis' intellectual inheritance. Their residence's doors are open to him, and there he engages in the same activities of the noble in the classical Bildungsroman: intellectual pursuit, conversation, and sports.

However, this bliss has a blind spot. Cristina Della Coletta argues that Carducci's letters of 1875 to Josette Artom most likely reflect the poet's political indecision on whether to support Agostino Depretis' moderately progressive course or Francesco Crispi's reactionary and imperialistic turn (143). Being the author of a gratulatory note to General Bava Beccaris for having opened fire on demonstrators in Milan in 1895, Josette Artom would have probably suggested

\footnotetext{
scrittore che, a quasi cinquant'anni, ricorda e giudica se stesso da giovane." ("Il giardino tradito" now in Opere 1263-64).

${ }^{23}$ For the implications of this suggestion, see Parussa 125.
} 
the latter. The reactionary turn in Italian politics is what, in 1922, made the Italian monarchy acquiesce to the rise of Fascism (Della Coletta, 144). The FinziContinis' anti-Fascist stand and flaunted liberality actually hides many uncomfortable memories. ${ }^{24}$

Meldolesi might have overlooked such implications; Giorgio certainly does not, but neither does he comment on them, and that indicates his limits. Giorgio is becoming more and more aware of the consequences of history, but in many ways he is still a conformist. His perspective oscillates between the one of the insightful mature author and that of the tentative young man in the making. $\mathrm{He}$ is aware of what surrounds him, but does not make any ideological commitment. Meaningfully, the paragraph describing Giorgio at work in the magna domus' library ends with the minimal camaraderie shared with Professor Ermanno, compared to the one shared years later with the inmates during incarceration. ${ }^{25}$ Eventually, the mature writer chooses compassion over judgment.

The character that could open Giorgio's eyes to the ambiguities of postunitary Italian history is Giampiero Malnate. He is only slightly older than Giorgio and the Finzi-Contini siblings, but his habits are considered those of an accomplished man, and perhaps a little flaunted as such. Micòl mocks him for it. For her, he is too bulky and too much like a father ("troppo 'padre" 428), and the pipe he smokes is "a flag of sub-Alpine, masculine austerity" (McKendrick 111; "un programma di austerità maschile e subalpina, tutta una bandiera." 429). Significantly, Micòl's description of him comes after her comments on the unrequited passion of aspiring poet Bruno Lattes for coquettish Adriana Trentini as good training for his future writing, since he seems almost addicted to suffering (428 and McKendrick 110). In so doing, she foreshadows, not only Giorgio's unrequited passion for her, but also young Giorgio's upcoming confrontation with the accomplished professional, already integrated in the workforce, busy with a regular work schedule, and living on his own. ${ }^{26}$

\footnotetext{
${ }^{24}$ See also note 5 about the novel being also an essay in history.

${ }^{25}$ It needs to be remarked that this is the only allusion to Giorgio's (and Bassani's) incarceration left in the whole Romanzo di Ferrara.

${ }^{26}$ The novel comes out in 1962, when Italy's industrial development was reaching its peak. Conceited professionals, embodying the enjoyment of male power at the expense of others both in the workplace and in private life, were frequent in literature and film. An example is Sandro,
} 
When he first meets Malnate, Giorgio tries hard to get his admiration and esteem. He even tries to imitate him, and even gets into the habit of smoking the pipe (451-52). As Giusi Oddo de Stefanis argues, Malnate becomes the immediate object of Giorgio's desire (171). Malnate's cocksure assertiveness makes him look like the true usher into adulthood, which convinces Giorgio to endure even his subtle emotional blackmailing intermixed within his arguments on politics. ${ }^{27}$ Initially, Malnate is indeed Giorgio's main source of validation. By accusing France and England of not really opposing to Hitler's aggression, Malnate brings Trotsky's argument to its extremes, and implicitly confirms the radical stand Giorgio took in front of his own father. Furthermore, Malnate's indictment of the Jews who espoused Fascism and did not foresee its hostility until the promulgation of the racial laws summarizes Giorgio's thoughts since the last chapters of Gli occhiali d'oro. ${ }^{28}$ Finally, in blaming also Italy's post-unitary liberal establishment for not having really opposed Mussolini's rise, Malnate clearly exposes the reactionary ghost of post-unitary Italy, the one that the Finzi-Continis try to ignore (if not to suppress).

Lucienne Kroha argues that "Malnate offers the model of an active, engaged masculinity that contrasts sharply with the passive demeanor of the Jewish man in the protagonist's entourage." ${ }^{29}$ It is an interpretation that I consider misleading. Since early on, Malnate's ways of behaving are, more than manly, clearly abusive. When he asks Alberto to reveal why he did not respond to Gladys, the young dancer who had a crush on him, Malnate not only tries to expose Alberto's feelings, but also enacts a malicious game of one-upmanship with his friend. In the past, by inducing Alberto to be with his own ex-girlfriend Gladys, Malnate tried to prove his superiority over his friend by dumping on him his former cheap and whorish lover "in fondo disinteressata, convenientemente puttana" (457). Once

\footnotetext{
interpreted by Gabriele Ferzetti, in Michelangelo Antonioni's L'avventura (1960). One should note that Micòl never shows or utters any positive appreciation for Malnate.

27 "Lo vedo ancora sporgere in avanti la grande testa bruna dalla fronte lustra di sudore, figgere gli sguardi nei miei, nel solito insopportabile tentativo di ricatto, tra morale e sentimentale, a cui ricorreva così volentieri, mentre la sua voce assumeva toni bassi, caldi, suadenti, pazienti." (452)

${ }^{28}$ Indicting the bourgeoisie for not having opposed Fascism when it was time is also one of Bassani's main ideological points throughout the Romanzo di Ferrara (Oddo De Stefanis 113-14).

${ }^{29}$ See Drama 142; but see also "Judaism and Manhood" 193.
} 
depreciated, the woman-object is passed over to the lower man in order; if he accepts her, he confirms his own subordination. In this way, Malnate would have power not only on Gladys, but also on Alberto's desire for her and therefore on him (Girard 1-52). A similar disparaging game happens between Leo Merumeci and Michele Ardengo in Alberto Moravia's Gli indifferenti: Leo's former lover Lisa now tries to seduce Michele, who shall accept her when he realizes that his own sister Carla has capitulated to Leo's pressing advances. When Leo finally wins, Michele accepts to lose.

Malnate's defense of socialism and communism is solid and articulated, but consists mainly of attacking his interlocutors with a combination of the ad hominem argument and the "straw man" tactic: he extrapolates the interlocutor's position mainly by presumption, misrepresents it, and finally demolishes it (Walton 118-20). He accuses Alberto, who has never taken care of his patrimony, of defending capitalist privilege, and Giorgio of being a spineless man of letters, who never took action and never will. These dummy identities have no supporting evidence; but, since there is no evidence of the opposite either, they cannot be disproved. Hence, Malnate gets away with his empty claims, while Alberto and Giorgio simply have to suffer from his blows.

At first, Giorgio chooses passive resistance, as typical of the Jewish minority in times of strong hostility, a position Kroha defines "cultural feminization" (Drama 24-39). Only later, when his own Jewish identity is in question, he stands up to Malnate, and defends his right to define it on his own, and not to subscribe to social expectations. In Lacanian terms, Giorgio rebuffs all fantasies about the Jewish condition:

One of the most odious forms of anti-Semitism was precisely this: to complain that Jews aren't sufficiently like other people, and then, the opposite, once they've become almost totally assimilated with their surroundings, to complain that they are just like everybody else (...) (McKendrick 142)

Una delle forme più odiose di antisemitismo era appunto questa: lamentare che gli ebrei non fossero abbastanza come gli altri, e poi, viceversa, constatata la loro pressoché totale assimilazione all'ambiente circostante, lamentare che fossero tali e quali come gli altri (...) (464) 
Giorgio opposes precisely that form of "straw man" tactics that constitutes the basis of racism at a social level: conventionally established figures (the Other) invested of unconscious desire that compensate for the ideological inconsistencies of a society (Žižek, Sublime Object 47-49). ${ }^{30}$ Malnate might protest that he is not antiSemitic, but he actually employs anti-Semitism's discursive tactic. If his flaunted maturity—spoofed by Micòl—bears no sign of paternity, Malnate certainly shows the aggressiveness of what Lacan calls the "real father." In confronting Alberto and Giorgio, he aims at making them uncomfortable, and not just to disabuse them of their naïve (and perhaps hypocritical) disregard of their privileged status, but really to forestall their enjoyment even in simply being in a conversation.

Malnate's malicious intentions come out more evidently during the evenings he spends with Giorgio alone in town. He belittles and dismisses Montale and Lorca, Giorgio's favorites, because of their lack of positivity (the "Yes" that the poet has to oppose to the adverse events). He prefers Carducci and Carlo Porta. To the Italian readership of the 1960s, Giorgio's favorites are two modern classics, whereas Malnate's are at least suspicious. Carducci's reactionary implications and undertones are clear, as it was said before. Even if Malnate indicts Carducci's late pro-monarchy attitude, the "Hymn to Satan," however blasphemous, is by no means original, and confirms his conservative categories of judgment. The same argument is valid for Carlo Porta, on which Bassani wrote an important short essay. ${ }^{31}$ For Bassani, Porta gives a voice to the poor. However, like Manzoni's, Porta's poor do not have a clear and mature sense of themselves and, prey to their own fantasies of heroism, they eventually become the laughingstock of the reader, who feels safer, smarter, and wiser. In the position of Porta's reader stands Malnate, who enjoys his own power, belittles Giorgio's modern tastes and opinions, and nurses a nostalgic fantasy of Lombardy that exists only in his mind.

As a literary style and a mental habit, realism not only does not equal awareness of reality, but could also easily become the opposite: a fetish for a figment of the imagination that bears no contradiction. Malnate declares he cannot bear the negative in a text, and considers only the affirmative. Such inability to infer

\footnotetext{
${ }^{30}$ A different point of view is that of Vladimir Jankélévitch, who considers assimiliation and differentiation as the two contradictory components of the Jewish identity, constantly oscillating between the two; cf. "Ressembler, dissembler (la conscience juive)," Sources: Recueil (Paris: Seuil, 1984, discussed in Parussa 10-26).

31 "I poeti dell'umile Italia" Il mondo, 6-7, and now with the title "Manzoni e Porta" in Opere (999-1003).
} 
meaning beyond the literal sense (of poetry, of all possible symbolic texts) is what Lacan calls "the imbecility of realism," according to which, sense is always selfevident. Lacan notoriously demonstrates the inadequacy of such habit in analyzing Poe's story "The Purloined Letter" (Écrits 17-18).

Malnate may be able to point at the reactionary ghost of post-unitary Italy, i.e., the monarchy that opened the way to power to Mussolini; but he does not have the appropriate cultural categories to counteract it. In fact, his praise of political action does not seem to go beyond his conversations with Giorgio and Alberto. He knows of the clandestine anti-Fascist parties in Ferrara, but does not seem to be at all involved with them. ${ }^{32}$ On the contrary, his praise of action, modernity, strength, and popularity is not very dissimilar from that of Fascism. His defense of Milan's rational planning, as opposed to Venice's oppressive wet cesspool ("quell'opprimente cesso bagnato" 547), for instance, seems to condense and summarize Filippo Tommaso Marinetti's invective "Contro Venezia passatista" (Marinetti 33-38). ${ }^{33}$

Similar to many of Marinetti's pronouncements, is also Malnate's disparaging attitude towards women. ${ }^{34} \mathrm{He}$ praises socialist activist and teacher Clelia Trotti, but talks at length only about prostitutes and the like (Gladys, the 'conveniently whorish' dancer who had a crush on Alberto). He acts like the dominant male who relates to women only insofar as they support and confirm his ego, like Marinetti's Mafarka. ${ }^{35} \mathrm{He}$ is the one who insists on visiting the brothel, after reciting two lines by Porta about a mercenary woman and the laughable longings of the fool who fell in love with her. Once more, Malnate, like Porta's reader, enjoys watching the loser struggle.

\footnotetext{
32 On the contrary, Giorgio Bassani was actively involved in anti-fascist politics since 1937. (See Alessandro Roveri, Giorgio Bassani e l'antifascismo, and Tra Micòl e il Partito d'Azione: le passioni del giovane Bassani). About Malnate, Bassani says: “(...) Malnate is a wreck (...) He says he dreams of a 'Lombard' and 'Communist' future, but he is just tied to miserly and mediocre domestic feelings." (interview in Camon 62).

33 The relationship between Futurism and Fascism is far more complex. Nonetheless, it is arguable that, in the 1960s, Marinetti is considered essentially a reminder of Fascism.

${ }^{34} \mathrm{He}$ is equally disparaging towards homosexuals. To him, Fadigati is a pitiful case destined to medicine or social prevention, as if homosexuality were a contagious disease. Similarly, Marinetti talks about "l'invertito-nato, il falso uomo, la mezza donna che non si corregge." (283)

${ }^{35}$ See Spackmann 7-16 and 46-76; see also Sartini Blum 88-90.
} 
In the brothel, Malnate can finally accomplish the coup that failed with Alberto: passing the vilified woman-object onto the lower-ranked man by letting Giorgio go off with a prostitute while he stands aside and proves his superiority. In this way, he controls Giorgio's desire and actually prevents him from enjoyment: the encounter was fast ("Everything happened very quickly" McKendrick 225) and it is all we know about it. The prostitute is a blonde with her hair drawn back above the cape of her neck, soberly dressed, like a high school girl from a good family; she even calls him "Celestino," the epithet chosen by Micòl. The episode is evidently a sordid parody of his true passion. Once out of the brothel, Malnate obviously eludes any friendly confidence about Giorgio's hard times with Micòl. Humiliation and castration: the real father's mission is finally accomplished.

Precisely after this episode, Giorgio returns home and talks to his actual father. The dialogue that Giorgio's father wanted since the beginning of the novel finally takes place. The dialectic father-son has here its crucial, pivotal moment. Giorgio's father no longer appears as the ideal Jewish father (the imaginary father), or even less as the Fascist loyalist antagonizing the rebellious son (the ideological castrator, the real father). He is an old, wise man, beyond reality and time, almost about to leave his body behind and become pure spirit:

It struck me how everything about him and around him was whitehis silver hair, his pallid, exhausted face, his white nightshirt, the pillow behind his kidneys, the sheet, the book open on his chest, and how that whiteness (a clinical whiteness, I thought at the time) was in keeping with the surprising and extraordinary serenity, the unexpected benign expression, full of wisdom, that lit up his bright eyes. (McKendrick 231)

Mi colpì come tutto, di lui e attorno a lui, fosse bianco: argentei i capelli, pallido e smunto il viso, candidi la camicia da notte, il guanciale dietro le reni, il lenzuolo, il libro posato aperto sul ventre; e come quella bianchezza (una bianchezza da clinica, pensavo) si accordasse alla serenità sorprendente, straordinaria, all'inedita espressione di bontà, piena di saggezza che gli illuminava gli occhi chiari. (560)

Giorgio's father immediately deflates Malnate's supposed high status as a mature professional: to him, Giorgio's friend from Milan may still be a university student, 
like his son. Then, in talking about the brothel, he turns Giorgio's humiliation into a normal fact of life. The dissolving Oedipal knot to which John Champagne refers (157-58) coincides, not just with the confirmation of the heterosexual norm but, more importantly-I contend-with Giorgio's relief, on the very ground of the heterosexual norm, from Malnate's power game of humiliation. A new bond ("On this subject there had never been any exchange of confidences" McKendrick $232)^{36}$ is therefore constituted upon the father's approval of his son, even if it is clear that, as heterosexual males, they are quite different from each other, as it emerges in their attitudes towards Doctor Fadigati. The father is obviously conservative and endorses the homophobia of his times, whereas Giorgio's compassionate understanding breaks through social conventions and reaches out to the discriminated. Nonetheless, they can finally have the conversation that they both needed since the beginning of the novel, when they contended about politics.

It is precisely on politics that they now agree. Giorgio's father has become aware of the imminent disaster. He no longer holds onto his bourgeois status, but, on the contrary, he sorrowfully realizes the many mistakes made by his generation and acknowledges them in front of his son. Even the last possible divergence about a compromise between Germany and the Soviet Union fades into the almost metaphysical anticipation of the Molotov-Ribbentrop Pact, to be actually signed in a few days (23 August 1939). The bond between father and son is confirmed when they come to an understanding of history, when they "seize a memory as it flashes up at a moment of danger" (Benjamin 255). That moment of danger is their present: August 1939, in a Jewish household in Ferrara. As a closure to the Freudian "family romance," it is from his own father that Giorgio finally finds the validation he has been looking for since his adolescence. Giorgio's actual father eventually becomes the symbolic father, i.e., the male adult that validates the son and introduces him into the symbolic order.

Lacan also specifies that the symbolic father, as a function, comes after the Oedipal killing. The symbolic father no longer shows the attributes of action and vitality that could override the son's own active partaking in life through the symbolic order: "(...) the symbolic Father, insofar as he signifies the Law, is truly the Dead Father" (Écrits 464). ${ }^{37}$ In the initial description, Giorgio's father already

\footnotetext{
36 ("Fra noi non c'era mai stata tanta confidenza, al riguardo." (561)

${ }^{37}$ On the dead father, the same suggestion comes from Enzo Neppi (384), but in a different perspective with very different implications which I do not share.
} 
looks like he is living beyond time and beyond his body. After the bond between father and son is established, Giorgio too lives in that dimension. Contrary to what Freud and (in part) Lacan affirm, the son's rise is not determined by the father's death:

He was speaking as if both he and I were already dead, and now, from a point outside space and time, together we were discussing life, everything which in the course of our respecting lives might have happened, but actually didn't. Would Hitler and Stalin reach an agreement? Yes, they most probably would (McKendrick 235-36, with modifications; emphasis mine)

Parlava (...) come se io e lui fossimo già morti, ed ora, da un punto fuori dello spazio e del tempo, discorressimo insieme della vita, di tutto ciò che nel corso delle nostre vite rispettive sarebbe potuto essere e non era stato. Si sarebbero messi d'accordo, Hitler e Stalin? - mi chiedevo anche. - Perché no? Molto probabilmente Hitler e Stalin si sarebbero messi d'accordo. (565, emphasis mine)

When all ideologies are about to collide and the world is soon to wreck, the Bildung of the young bourgeois pursuing social integration through the habits of the noble obviously shows its complete inadequacy. The Finzi-Continis have allowed Giorgio to continue his life habits for a few months; but history has moved far beyond the Racial Laws. Society is about to crumble, and accepted norms and rituals, like engagement and marriage, become as remote as fiction.

Il giardino indeed revisits the structure of the nineteenth-century Bildungsroman and adds some elements of the early twentieth-century's, but only to show its total inadequacy to the times. Contrary to what happens in Goethe, Stendhal, or Dickens (with content), but also in Thomas Mann, James Joyce, or Robert Musil (with discontent), the young intellectual cannot find his place in society. Why? Because there is no longer a society in which to find a place, especially for a young writer, who lives on his ability to understand people's feelings and communicate them. Giorgio does indeed have the insight and compassion to do that, but, in times of emergency, those qualities that were once social facilitations, have become obstacles, or so Giorgio's father thinks: "You are too sensitive, that's what I mean, and so never satisfied...” (McKendrick 236) Implicit approval 
indeed comes with worries, that, coupled with regrets, make Giorgio's father feel paralyzed in front of the times to come. These are his suggestion to Giorgio:

Don't go around their house any more. Start studying again, get busy with something, maybe start tutoring-I have been hearing that there's great demand for it... And don't go around there any more. Besides, it's more manly not to.

He was right. Besides, it was more manly not to. (McKendrick 237 with modifications)

"Non andarci più a casa loro. Ricomincia a studiare, occupati di qualcosa, mettiti magari a dare delle lezioni private, che sento dire in giro che ce n'è tanta richiesta... E non andarci più. È più da uomo, fra l'altro."

Aveva ragione. Fra l'altro era più da uomo. (567, emphasis mine)

Da uomo does not simply translate as "manly," but also as "like a man," "as a man," or "for men"; it is said for clothes, and strongly marks gender roles. As if he could finally wear long pants (calzoni lunghi da uomo), Giorgio has grown into his own role, and has to accept the responsibilities and prerogatives that come with it. The former are indeed many, however, and the latter are few and unattractive: they amount to his reading room at the end of the corridor for studying and tutoring, which, compared to the opportunities of the protagonists of the Bildungsroman (even in its modernist version), is almost nothing.

Obviously, Giorgio is not ready to accept his new role. His obsession for Micòl still persists. In his wanderings, every corner reminds him of his renunciation. Unconsciously, he gets to the very spot of the ramparts facing the Barchetto del Duca, where he first talked to Micòl, when they were sixteen and she appeared to him as an object of desire. ${ }^{38}$ On that very wall of the Barchetto del Duca, Micòl becomes what Lacan calls the Thing: a common object that becomes invested with the subject's drive, since sublimation "raises an object (...) to the dignity of the Thing." (Seminar VII 112). Sublimation does not happen spontaneously, however: "(...) the sublime quality of the object is not intrinsic, but rather an effect on its position in the fantasy space." (Žižek, Looking Awry 84). Micòl occupies precisely

${ }^{38}$ It did not really happen before. At the synagogue, Micòl returned Giorgio's gaze, but he looked far more intensely at Professor Ermanno. 
the position of the object of desire in Giorgio's fantasy space, which corresponds to the garden of the Finzi-Contini (precisely the title of the novel).

At the sight of the ladder by the wall, Giorgio decides to get into the garden and enter his own fantasy space. In his fantasy, Giorgio is even more obsessed with Micòl, now that she is out of his reach. She is a constant reminder of his own frustration. If he is the victim, the aggressor is Malnate, who humiliated him at the brothel and made him undergo the sordid parody of his passion. Therefore, even if Micòl never expressed anything but gibe about Malnate, the two must have an affair, which would confirm Giorgio's frustration. That happens in Giorgio's fantasy, of course, and only there.

At the toll of the town clock, Giorgio's fantasy disappears, and so do his fancy for Micòl and his rancor towards Malnate. The sublime object exists only "in the shadow (...) as something implicit, evoked: as soon as we try to cast away the shadow to reveal the substance, the object itself dissolves." (Žižek Looking Awry 83-84). The clock's toll finally casts away the shadow of Giorgio's fascination with the garden and with his role in it: that of the protagonist of an impossible, outdated, fictitious Bildungsroman. He recognizes the nature of his obsessive thoughts as fiction and eventually concludes precisely: "What a great novel!" (McKendrick 245; "Che bel romanzo!" 576) The clock's sound also reminds Giorgio of his father and of the symbolic order he has entered: responsibilities, daily duties, other roles to be embraced. It is time to leave fantasies behind and live in reality, time to behave like a man (comportarsi da uomo) and face the hard times ahead. ${ }^{39}$

Bassani's original plans for Giorgio were far more ambitious, as he states in a letter to his friend and scholar Lanfranco Caretti of 13 July 1958 (Caretti 12-13). Gli occhiali d'oro was supposed to be the first short novel of a trilogy. The second one should have focused on Giorgio in prison in 1943 (Bassani was incarcerated for three months in that year) and on his Fascist custodian Eraldo Deliliers (Fadigati's former unfaithful, parasitical, and dismissive lover in Gli occhiali d'oro),

\footnotetext{
${ }^{39}$ Slavoj Žižek's observation on the dissolution of the sublime are based on Alfred Hitchcock's Vertigo (1958), which presents a similar ending to that of Bassani's novel. The subject ("Scottie" Ferguson, interpreted by James Stewart) recognizes the sublime object of his desire (Madeleine, interpreted by Kim Novak) only when she is properly clothed, coiffed, and brought to scene of her (supposed) death. When she reveals the plot, the man's fantasy dissolves. Hitchcock's film came out in Italy with the title La donna che visse due volte in 1958, when Bassani, a passionate moviegoer, had started working on Il giardino. On other correspondences between Bassani and Hitchcock, cf. Maurizio Del Ministro, "La conoscenza e la diversità nell'opera di Bassani" (Antognini and Diaconescu-Blumenfeld, 571-87).
} 
who lets Giorgio live and later dies in unknown circumstances. In the third novel of the trilogy, successful journalist and writer Giorgio (Bassani received the Strega Prize in 1956) returns to Ferrara years later and realizes that Deliliers was killed by the partisans. Having been both a militant partisan and the recipient of Delilier's confessions, Giorgio understands both sides of the fight and has a complete picture of the events.

Bassani's planned trilogy most likely intended to depict Giorgio as the intellectual hero of post-war democratic Italy. In the first part, empowered at the sight of Ferrara's Jewish cemetery, Giorgio realizes his diversity as a Jew and the struggle he shall face, and dismisses all fear. ${ }^{40}$ In the second part, in jail, he has to suffer the double pressure of incarceration and of collecting his persecutor's confidences. In the third part, after the war, ex-partisan and convinced anti-Fascist Giorgio, privy to the confessions of Fascist vilain Deliliers, can realize the incoherence of socialist politician and former partisan Nino Bottecchiari. At a time when Italy was still reluctant to cope with its recent past, Giorgio would have been aware of all its contradictions. The protagonist of the unwritten "further stories from Ferrara" would have been sensitive and reflective, like Bruno Lattes, but skeptical and determined like Geo Josz. Most importantly, however, he would have been much more similar to his own author, Giorgio Bassani, who was closely involved with the clandestine Partito d'Azione from 1937 until after the end of the war. ${ }^{41}$

Instead, in the final version of the Romanzo di Ferrara, the story of Giorgio's adult life ends when he exits the garden. Readers shall know nothing about his life as a man, da uomo. After Il giardino, Bassani eagerly worked at Dietro la porta (1964), which features Giorgio at age sixteen, precisely after the summer when he met Micòl on the garden wall, by the city's ramparts. He passed his remedial exam in math, and he is about to start a very bleak school year. No longer soothed by Meldolesi's encouragement, his ego ideal of the future intellectual shall

\footnotetext{
${ }^{40}$ Enzo Neppi has a similar interpretation (389 note). Conversely, Lucienne Kroha thinks that the "ancient maternal face" of Ferrara signs the persistence of a "narcissistic pre-Oedipal relation with the mother," stifling and depriving the subject of his independence (Drama 101-03). Her essentially Freudian interpretation (in many aspects convincing) is based on an evaluation of the whole Romanzo di Ferrara's final version. Mine and Neppi's are probably more adequate to Bassani's original plans (for what we know of them).

${ }^{41}$ See Alessandro Roveri, Giorgio Bassani e l'antifascismo, very rich and informative. Roveri's Tra Micòl e il Partito d'Azione: le passioni del giovane Bassani offers an equally useful background of facts for the novel, and a summary of Bassani's clandestine militance (32-53).
} 
suffer the humiliating retorts of conceited, self-concerned, and almost sadistically ironic Professor Guzzo (in assonance with aguzzino, i.e. 'torturer'). Outside the classroom, he is about to be bullied and slandered by his schoolmate Luciano Pulga, an even more subtly aggressive and malicious younger Malnate. In the final version of the Romanzo di Ferrara, Giorgio's courage in facing a society that shall disparage his diversity, seems to give way to his difficulty in negotiating his own identity, particularly his own masculinity. Since most of the main characters in the Romanzo di Ferrara are men, as mentioned above, there is no doubt that masculine identity is crucial throughout it (especially in the Giardino, given its central position) and deserves thorough investigation and more space (and necessarily needs to take into account the relationship to Micòl). In form of conclusion, I can reasonably offer some observations necessary to such discussion. ${ }^{42}$

Of all the characters in the novel, Malnate is the one who poses the steepest challenges and obstacles to Giorgio's expression of his own masculine identity, and also the one who strongly antagonizes his tastes. The two most harshly contended authors are painter Giorgio Morandi and poet Eugenio Montale, whom Malnate accuses of rejecting positive action. On the contrary, in 1959 ex-partisan Italo Calvino recognizes them as fundamental models:

The rigor of Montale's poetry, the rigor of Giorgio Morandi's paintings, those still lives of bottles in which the cold exactness of light envelops the humble reality of things (...) taught us to hold to the essential in everything; they taught us that what we can be sure of is very little and must be endured to the very end. It was a lesson in stoicism. (Quoted in Biasin 44)

Morandi and Montale's lesson in stoicism, as suggested by Calvino, is the subject of chapter two in Gian Paolo Biasin's Montale, Debussy and Modernism. ${ }^{43}$

\footnotetext{
${ }^{42}$ I am aware that the discussion has already started with John Champagne's book Aesthetic Modernism and Masculinity in Fascist Italy, but, since it should involve more aspects of Bassani's novel than I have decided to examine here, I need to defer it. However, I anticipate that I am not convinced that "queer" is the proper category to understand the Giardino and his narrator. Giorgio does not question his heterosexuality, but wants to negotiate his own way to it. In part he fails (Micòl rejects him) and in part he succeeds (the father essentially approves his son's character).

${ }^{43}$ Gian Paolo Biasin, Montale, Debussy, and Modernism, or Il vento di Debussy: la poesia di Montale nella cultura del Novecento.
} 
Morandi's still lives and solitary landscapes are the signs of pictorial and existential understatement. In Francesco Arcangeli's words, Morandi "has slowly come to affirm and ascertain, a human possession of the world and things." (Biasin, 58). ${ }^{44}$ Rhetorical understatement ("diminutio antiaulica" 60) is the core of Morandi's anti-fascist attitude, which holds true for Montale as well. In "Meriggiare pallido e assorto," for instance, the human subject, not in the scene, observes the objects as they develop through the forms of poetry. (Biasin, 59-68) For this reasons, Biasin remarks, Montale's poetry presents a subject that stands for a clearly antifascist ethic of understatement: Giorgio espouses it wholeheartedly, while Malnate misses it completely.

Furthermore, according to Biasin ("Strategies of the Antihero", 68-107), the ethic of existential understatement defines a fundamental character in Italian and European literature: the modern antihero, the misfit past the age of adaptation to society (and therefore of the Bildungsroman), whose realization of the conventional nature of social standards gives him further insight into the world, if less ability to accomplish his purposes (but not in all cases). In his condition of disharmony and emargination, the antihero "must have a strategy on his own: he must somehow use the weapons provided by the environment for his own ends." (Biasin, 78) The fundamental examples in Italian literature are Zeno in Svevo's La coscienza di Zeno (1923) and Vitangelo Moscarda in Uno, nessuno e centomila (1925). ${ }^{45}$ Beside them stands the protagonist of a "true novel of identity" (Luperini, in Biasin, 71), an antihero whose insecurity and hyperawareness are similar to those of Svevo's and Pirandello's characters: the speaking subject of Montale's Ossi di seppia. The speaking subject of Montale's first poems confronts reality and explores his own awkward and contradictory relationship about it, through a sequence of texts that starts by acknowledging his own limits in "In limine" and ends with the mere wish of a possible regeneration in "Riviere." 46

Giorgio confronts Malnate with "Non chiederci la parola." Negativity, the main matter of contention, is interpreted in opposite ways. Malnate considers it

\footnotetext{
${ }^{4}$ Today his phrase should probably be reformulated: what is reached, more than human possession, is human recognition.

${ }^{45}$ About the genre at large in European literature, see Victor Brombert, In Praise of Antiheroes: Figures and Themes in European Literature 1830-1980.

${ }^{46} \mathrm{He}$ is once foregrounded as a character and addressed in the second person in "Arsenio," whom Biasin closely compares to Zeno Cosini and Vitangelo Moscarda.
} 
a general, definitive "no," a great refusal that cannot generate poetry,which needs the poet's Yes. (McKendrick 214) The text-and most likely Giorgio as wellmeans something different: it definitely rejects any premature and unproblematic definition of the self for the sake of others-which reminds of Giorgio's defense of his right to reject all stereotypes imposed on his Jewish identity-or a formula that could explain everything once and for all. Why? Because the subject (plural, in the poem), has just started his journey: the poem in question is one of the earliest of the collection, the very first of the eponymous inner section ("Ossi di seppia," or cuttlefish bones) that presents the subject's early ways of relating to the world, mainly_as to be expected - through negation.

The relevant clues come in the two last lines, emphasized (by both Montale and myself): "All we can tell you today is what we are not, what we do not want" ("Codesto solo oggi possiamo dirti: / ciò che non siamo, ciò che non vogliamo." Montale, 29) The rejection of the features and values not endorsed by the subject is the first step towards defining one's identity, but only the first one. It is an early, temporary accomplishment, which bears the date of today; certainly not a definitive one. By quoting it, Giorgio implicitly acknowledges that he is still at the beginning of his journey. Nonetheless, even a few syllables, crooked and dry as branches, can be part of the strategy that the antihero needs to survive. Giorgio is still too young to be an antihero, but shows the signs of one. In this sense, his education is yet to come.

Ironically, almost at the end, the protagonist of a hypothetical—but, as we have seen, impossible-Bildungsroman, i.e. a novel of social integration, shows the signs of the budding social misfit, destined to a condition of dissonance, but also endowed with the privileged insight on society as a theater of empty, conventional roles. The outmoded, almost parodial version of the novel of education / integration could convert into its complementary opposite. Furthermore, if the parody of the Bildungsroman takes place in the garden of the Finzi-Continis, its complementary opposite could take place only when Giorgio definitely exits and shall have to fend for himself. Montale's lines could simply prepare him for what is to come, inasmuch as they prepared Calvino and many other readers of his generation, who fought in the resistance army.

However, precisely after exiting the garden, Giorgio makes his great refusal: nothing of his adult life shall be known. In front of the real tragedy of the Shoah (and not simply of Zeno's fantasized cosmic nebula) that took the lives of everyone in the novel but his, Giorgio decides to leave the limelight and omit the story of 
his own action and survival. In front of Auschwitz, his life becomes insignificant. What deserves to be told, instead, are the stories of those who would later die; not in order to investigate them thoroughly or to understand them fully, but simply to honor them with compassion and "the little that the heart has been able to remember." ("quel poco che il cuore ha saputo ricordare", 578). In an interview, Bassani declared that the novel's success certainly depended on many other reasons besides his author, and that he himself was far less worthy than the novel itself ("Io valgo molto meno del Giardino dei Finzi-Contini." 1261)

C. P. Cavafy, in his poem "Che fece... il gran rifiuto," says: "He who refuses shall not repent ... Yet that no-the right no-undermines him all his life." (12) Similarly, Giorgio's great refusal undermines the whole Romanzo di Ferrara. Two years after the Giardino, Bassani publishes Behind the Door (Dietro la porta, 1964), featuring Giorgio as the narrator and protagonist of an episode of betrayal and slander during his adolescence that, he says, shall mark him for the rest of his life as vile and inept. ${ }^{47}$ Instead of disproving Malnate's accusations of ineptitude and indecisiveness, Giorgio seeks to confirm them. From Behind the Door onwards, antiheroes in Bassani no longer show the potentiality of resisting power, of saying "no" only temporarily, and wait for the right moment to declare the great Yes, in Cavafy's (and also in Malnate's) words. On the contrary, Giorgio in Behind the Door, Edgardo Limentani in The Heron (L'airone, 1968) and many others, become emblems of stern rancor and unredeemable frustration. For them, personal dignity is a dream that will never come true (Ferraris, 37). In its outmoded structure of parodial Bildungsroman, that highlights the crucial events of the months between the approval of the Racial Laws and the beginning of WWII, the Giardino dei Finzi-Contini is indeed a turning point in Bassani's work, both for what it says and for what it compelled the author to omit, for its great Yes and for its great No.

\section{University of Massachusetts, Amberst}

\footnotetext{
47 "Slow to understand, nailed by birth to a fate of desperation and resentment, it was pointless for me to think of throwing open the door behind which I was hiding yet again. I would have never been able to do it, no way. Not now, not ever." (Kroha, Drama 187) "Duro a capire, inchiodato per nascita a un destino di separazione e di livore, la porta dietro la quale ancora una volta mi nascondevo inutile che pensassi di spalancarla. Non ci sarei riuscito, niente da fare. Né adesso, né mai." (699)
} 


\section{Works Cited}

Antognini, Roberta, and Rodica Diaconescu-Blumenfeld. (eds.) Poscritto a Giorgio Bassani: saggi in memoria del decimo anniversario della morte. Milano: Edizioni Universitarie di Lettere Economia Diritto, 2012.

Bakhtin, Mikhail M. Speech Genres and Other Late Essays. Tr. Vern W. McGee. Austin: University of Texas Press, 1986.

Barenghi, Mario. "Lo sguardo di Jor: per una rilettura de Il giardino dei FinziContini." Il romanzo di Ferrara, ed. Paolo Grossi, cit. (89-100)

Bassani, Giorgio. Opere. Ed. Roberto Cotroneo. Milan: Mondadori, "I Meridiani," 1998.

Bausi, Francesco: "Il giardino incantato: Giorgio Bassani lettore di Thomas Mann." Lettere italiane. 55.1 (2003): 219-48.

Benassi, Anna. (ed.) Un autore, una città: interviste con Giorgio Bassani, Carlo Bernari, Alberto Bevilacqua, Alberto Moravia, Giavanni Testori, Paolo Volponi. Rome: ERI, 1982.

Benjamin, Walter. Illuminations. Edited with an Introduction by Hannah Arendt. Trans. Harry Zohn. New York: Schocken Books, 1968.

Biasin, Gian Paolo. Montale, Debussy, and Modernism. Princeton: Princeton University Press, 1989.

Brombert, Victor. In Praise of Antiheroes: Figures and Themes in Modern European Literature 1830-1980. Chicago and London: The University of Chicago Press, 1999.

Calvino, Italo. "Main Currents in Italian Fiction Today." Italian Quarterly, 4.1314 (Spring-Summer 1960): 3-14.

Camon, Ferdinando. Il mestiere di scrittore: considerazioni critiche. Milano: Garzanti, 1973.

Caretti, Lanfranco. "Un vecchio appunto su Bassani." In Chiappini and Venturi (9-15).

Cavafy, C. P. Collected Poems. Ed. George Savidis. Tr. Edmund Keeley and Philip Sherrard. Revised Edition. Princeton: Princeton University Press, 1992.

Cazzola, Claudio. "Koré l'oscura: (in)seguendo Micòl." In Antognini and Diaconescu-Blumenfeld (271-301).

Champagne, John. Modernism and Masculinity in Fascist Italy. London and New York: Routledge, 2012. 
Chiappini, Alessandra, and Gianni Venturi. (eds.) Bassani a Ferrara: le intermittenze del cuore. Ferrara: Corbo, 1994.

Del Ministro, Maurizio. "La conoscenza e la diversità nell'opera di Bassani.” Antognini and Diaconescu Blumenfeld (571-84).

Della Coletta, Cristina. "La cultura del giardino: miti e appropriazioni letterarie nel Giardino dei Finzi-Contini." Modern Language Notes. 113.1 (January 1998): 138-63.

Durante, Lea. "L'io suddiviso, l'io distribuito: identità e autobiografia nel Romanzo di Ferrara." Il romanzo di Ferrara, ed. Paolo Grossi, cit. (181-93).

Ferraris, Denis. "La figure de l'antihéros dans l'œuvre de Bassani”, in Il romanzo di Ferrara, ed. Paolo Grossi (17-37).

Freud, Sigmund. The Ego and the Id. Tr. Joan Riviere, revised and edited by James Strachey. New York: W. W. Norton, 1989.

. "Family Romance." The Freud Reader. Ed. Peter Gay. New York and London: W.W. Norton, 1995 (297-300).

. Totem and Taboo. Translated and edited by James Strachey. New York and London: W. W. Norton, 1989.

Genette, Gérard. Narrative Discourse: an Essay on Method. Tr. Jane E. Lewin. Ithaca, NY: Cornell University Press, 1980. Translation of "Discours du récit." Figures III. Paris: Gallimard, 1972.

Girard, René. Deceit, Desire, and the Novel: Self and Other in Literary Structure. Tr. Yvonne Freccero. Baltimore, MD: The Johns Hopkins University Press, 1965. Or. Mensonge romantique et vérité Romanesque. Paris: Grasset, 1961.

Grossi, Paolo, ed. Il romanzo di Ferrara: atti del convegno internazionale di studi su Giorgio Bassani (Parigi, 12-13 maggio 2006). Paris, France: Istituto Italiano di Cultura, 2007.

Hainsworth, Peter, and David Robey. Italian Literature: a Very Short Introduction. Oxford and New York: Oxford University Press, 2012.

Homer, Sean. Jacques Lacan. "Routledge Critical Thinkers." London and New York: Routledge, 2005.

Kroha, Lucienne. The Drama of the Assimilated Jew: Giorgio Bassani's Romanzo di Ferrara. Toronto: University of Toronto Press, 2014. . "Judaism and Manhood in the Novels of Giorgio Bassani." The Italian Jewish Experience. Ed. Thomas DiNapoli. Stony Brook, NY: Forum Italicum Publishing (185-97). 
. "The Same and / or Different: Exile in Giorgio Bassani's Novels." Annali d'Italianistica. 20 (2002): 307-24.

Lacan, Jacques. Écrits. Tr. Bruce Fink, in collaboration with Héloïse Fink and Russell Grigg. London and New York: W. W. Norton \& Company, 2002. . The Seminar, Book I: Freud's Papers on Technique, 1953-54. Trans. John Forrester (with notes). London and New York \& Company: Norton, 1988. . The Seminar, Book II: The Ego in Freud's Theory and In the Technique of Psychoanalysis, 1954-55. Ed. Jacques Alain-Miller, Trans. Sylvana Tomaselli. London and New York: W. W. Norton \& Company, 1991. . Le Séminaire, Livre IV: la rélation d'objet. Ed. Jacques-Alain Miller. Paris: Seuil, 1994.

. The Seminar, Book VII: the Ethics of Psychoanalysis: 1959-1960. Translated with Notes by Denis Porter. New York, W. W. Norton \& Company: 1992.

Lejeune, Philippe. “The Autobiographical Contract.” Trans. R. Carter. French Literary Theory Today. Ed. Tzvetan Todorov. Cambridge and New York: Cambridge University Press, 1982. (192-222) Translation of "Le pacte autobiographique.” Le pacte autobiographique. Paris: Seuil, 1975. (13-46).

Marinetti, Filippo Tommaso. Teoria e invenzione futurista. Ed. Luciano De Maria. "I Meridiani." Milano: Mondadori, 1983.

McKendrick, Jaimie, trans. The Garden of the Finzi-Contini. By Giorgio Bassani. London: Penguin Books, 2003.

Moloney, Brian. "Giorgio Bassani, James Joyce and the Storie ferraresi." Journal of Anglo-Italian Studies. 5 (1997): 231-43.

Montale, Eugenio. Tutte le poesie. Ed. Giorgio Zampa. Milano: Mondadori, 1984. Moretti, Franco. Signs Taken for Wonders: Essays in the Sociology of Literary Forms. Trans. Susan Fischer, David Forgacs, and David Miller. London: Verso, 1988. Or. Segni e stili del moderno. Torino: Einaudi, 1980. . The Way of the World: the Bildungsroman in European Culture. Trans. Albert Sbragia. London: Verso, 2000. Or. Il romanzo di formazione. $2^{\text {nd }} \mathrm{Ed}$. Torino: Einaudi, 1999.

Neppi, Enzo. "Realtà e fantasma nel Romanzo di Ferrara di Giorgio Bassani." Italian Culture. 8 (1990): 377-91.

Nezri-Dufour, Sophie. Il giardino dei Finzi-Contini: una fiaba nascosta. Ravenna, Italy: Fernandel, 2012.

Oddo de Stefanis, Giusy. Bassani entro il cerchio delle sue mura. Ravenna: Longo, 1981. 
Parks, Tim. "Gardens and Graveyards." The Fighter. London: Vintage Books, 2007 (15-28). Originally in The New York Review, July 14, 2005.

Parussa, Sergio. Writing as Freedom, Writing as Testimony: Four Italian Writers and Judaism. Syracuse, NY: Syracuse University Press, 2008.

Roveri, Alessandro. Giorgio Bassani e l'antifascismo. Ferrara: G2, 2008.

. Tra Micòl e il Partito d'Azione: le passioni del giovane Bassani. Scandicci, Italy: Firenze Atheneum, 2009.

Sartini Blum, Cinzia. "Marvellous Masculinity: Futurist Strategies of Self-Configuration through the Maelstrom of Modernity." Modernism and Masculinity. Ed. Natalya Lusty and Julian Murphet. New York: Cambridge University Press, 2014 (87-102).

Scotto Di Luzio, Adolfo. Il liceo classico. "Lidentità italiana” 15. Bologna: Il Mulino, 1999.

Spackmann, Barbara. Fascist Virilities: Rhetoric, Ideology, and Social Fantasy in Italy. Minneapolis: Minnesota University Press, 1996.

Venturi, Gianni. "Prime risultanze di uno scrittore." Ritorno al Giardino: una giornata di studi per Giorgio Bassani. Ed. Anna Dolfi and Gianni Venturi. Rome: Bulzoni, 2006 (15-28).

Walton. Douglas. “The Straw Man Fallacy." Logic and Argumentation. Ed. Johan van Bentham, Frans H. van Eemeren, Rob Grootendorst, and Frank Veltman. Amsterdam: Royal Netherlands Academy of Arts and Sciences, NorthHolland, 1996. (115-28). PDF downloaded on 30 July 2014 from http:// www.dougwalton.ca > papers > The Straw Man Fallacy.

Wisse, Ruth R. No Joke: Making Jewish Humor, Princeton, NJ. Princeton University Press, 2012.

Žižek, Slavoj. Looking Awry: An Introduction to Lacan Through Popular Culture. Cambridge, Mass, and London, England: The MIT Press, 1991. . The Sublime Object of Ideology. London: Verso, 1989. 